\title{
Estimated travel time between the city (Case study: Waru Street-Mojokerto)
}

\author{
Budi S. Waloejo ${ }^{1, *}$, Dadang Meru Utomo ${ }^{1}$, and Ninditarari Salsabila $\mathrm{W}^{1}$ \\ ${ }^{1}$ Brawijaya University, Faculty of Engineering, Malang, Indonesia
}

\begin{abstract}
The area in Surabaya and Mojokerto is an industrial area that is increasing quite rapidly. Based on City Mojokerto in Figures Year 2016. From an industrial estate is a change of land use from agriculture or ponds into settlements and / or industries. The occurrence of congestion along this road because of the capacity that is not sufficient to accommodate the number of vehicles passing. The purpose of this research is to know the model of land use interaction, knowing the network performance and know the travel time to be passed. And analyze what components affect the calculation of travel time. Necessary data. The existing land layout along the road and the average traffic calculation data on the road in the study area. To know the travel time must be known in advance the capacity of the road that can be accommodated along the road. After the capacity is known the service performance becomes the main factor in determining road network performance. This research uses regression analysis for land use modeling.
\end{abstract}

\section{Preliminary}

Transportation is a tool used to move people or goods from the place of origin to the destination. Various types of transportation facilities that have developed rapidly raises various problems, one of which is the growth of the number of motor vehicles is not directly proportional to the growth of the road $[1,2]$. The number of motor vehicles in Indonesia each year has increased. Based on data from the Traffic Police Corps, until July 2016 the population of vehicles in all parts of Indonesia reached 124,348,224 units. Each year vehicle growth reaches six million units per year and about 10-15 percent is the contribution rate of four-wheeled vehicles. According to the Chairman of the Association of Indonesian Automotive Industries (Gaikindo), road growth in Indonesia only reaches an average of 0.08 percent. Growth in the number of motor vehicles will result in traffic conditions that decline in quality of service, and cause discomfort such as congestion.

In addition to increasing the number of vehicles, the cause of congestion is the reduction of effective space of roads caused by parking of vehicles and / or activities of street hawkers on the shoulder of the road. Surabaya city development is very rapidly also shows the development towards the outskirts of the city directly adjacent to the city of Surabaya, such as Sidoarjo, Gresik, and Mojokerto. The border area of Surabaya and Mojokerto is an

* Corresponding author: budieswe@yahoo.co.id 
industrial area that increases quite rapidly. Based on Mojokerto City In Figures 2016, the impact of increasing industrial area is a change of land use function from agriculture or pond into settlement and / or industry. Land use functions to influence urban congestion. The land will form the pattern of the resurrection zone, destination zone, and traffic volme. In an urban area it is characteristic that land use will be concentrated at one point which will result in over capacity. Reviewing that these 2 cities are the Center for Area Activity (PKW), which is filled with road users every day from and going to Mojokerto or vice versa. The occurrence of congestion along the road is due to insufficient road capacity to accommodate the number of vehicles passing by. If the capacity of the road network is almost saturated, then what will happen is a traffic jam that has adverse impacts on the social, economic, and environmental aspects. One of them is the loss of time for the wasted riders because it is spent on the road and the less productive time to work. So, with this research is expected to provide direction in the form of providing information in the form of traffic volume conditions for road users. Then the road user can choose and determine the route of the journey that will be passed.

\section{Research methodology}

This research is descriptive research where research which aim to describe about an event or situation. This study aims to produce a systematic, factual, and accurate information related to the characteristics of a particular population or region. In addition, this study is categorized as a correlation study to determine the level of variation in a bound factor or other factors based on the correlation coefficient. A qualitative approach is undertaken to determine the condition of the study area and the behaviour of the visitors of the land. Quantitative approach in this research is used to process linear regression model in order to get direction of problem handling strategy that happened in every field. Data collection methods used are: primary survey consists of; observations, interviews, and questionnaires. The secondary survey consists of; previous study surveys, agency surveys, and literature studies. Analytical methods used are qualitative analysis in the form of analysis of physical characteristics and road network and traffic characteristics. While quantitative analysis in the form of analysis of road network loading characteristics, free flow velocity analysis, and regression analysis. Additional analysis of the calculation of travel time calculation. To know the travel time must be known in advance the capacity of the road that can be accommodated along the road. Once the capacity is known to be obtained the level of service road that becomes the main factor in determining road network performance. The calculation of road capacity uses the following calculations [1]:

$$
C=\operatorname{Co} x F C W x F C S P x F C S F x F C C S
$$

Where:

$\begin{array}{ll}\text { C } & =\text { Capacity (smp / hour) } \\ \text { Co } & =\text { Basic Capacity (smp / hour) } \\ \text { FCW } & =\text { Traffic Length adjustment factor } \\ \text { FCSP } & =\text { Median Adjustment Factor or Direction Separator } \\ \text { FCSF } & =\text { Side Constraint Adjustment Factor } \\ \text { FCCS } & =\text { City Size Adjustment Factor }\end{array}$


Road network performance or service level using the following calculation [1].

$$
\begin{gathered}
V C R=V / C \\
V C R=\frac{\sum V i+\sum V_{\text {Ektermal }}}{C}
\end{gathered}
$$

Where,

VCR = Ratio Volume Capacity (service level indicator)

$\mathrm{V} \quad=$ Traffic Volume (pcu / hour)

$\mathrm{Vi} \quad=$ Amount of Vehicle Volume from Rise / Pull of Land

Vexternal $=$ Amount of Ongoing Vehicle Volume On Main Street

C $\quad=$ Road Capacity (pcu / hour)

If the road capacity and road network performance is known then the calculation of travel time as follows [1].

$$
t=\frac{\sum D}{V}
$$

Where,

$\mathrm{t} \quad=$ Travel Time (hours)

$\Sigma \mathrm{D}=$ Distance $(\mathrm{km})$

$\mathrm{V}=$ Velocity $(\mathrm{km} / \mathrm{h})$

\subsection{Research variable}

The location of this research study is located at Jalan Waru which is the final boundary of Surabaya that will go to Mojokerto. The required data are land use type along the road segment and the average daily traffic data that can be obtained from the traffic counting result. The model of the rise and pull used to take the form of correlation between variables, land use, or land use characteristics from the study area as the response variable and the number of activities in the land use as explanatory variables [3, 4, 5]. Explanation of

\begin{tabular}{|c|c|c|}
\hline No & $\begin{array}{l}\text { Response variable } \\
\text { (Dependent variable) }\end{array}$ & $\begin{array}{c}\text { Explanatory Variables } \\
\text { (Variable Free) }\end{array}$ \\
\hline 1 & $\mathrm{Y}_{\text {Housing }}$ & $\begin{array}{l}X_{1}=\text { Number of Family Members } \\
X_{2}=\text { Number of Motor Vehicles } \\
X_{3}=\text { Number of Household Income }\end{array}$ \\
\hline 2 & Y $_{\text {PTN/PTS }}$ & $\begin{array}{l}\mathrm{X}_{4}=\text { Building Area } \\
\mathrm{X}_{5}=\text { Number of Students }\end{array}$ \\
\hline 3 & $\mathrm{Y}_{\mathrm{TK}-\mathrm{SMK} / \mathrm{SMU}}$ & $\begin{array}{l}\mathrm{X}_{6}=\text { Number of Students } \\
\mathrm{X}_{7}=\text { Number of Teachers } / \text { Staff } \\
\mathrm{X}_{8}=\text { Number of Classes }\end{array}$ \\
\hline 4 & $Y_{\text {Pertokoan }}$ & $\mathrm{X}_{9}=$ Number of Visitors \\
\hline 5 & $\mathrm{Y}_{\mathrm{SPBU}}$ & $\mathrm{X}_{10}=$ Number of Employees \\
\hline 6 & $Y_{\text {Kantor }}$ & $\begin{array}{l}\mathrm{X}_{11}=\text { Number of Employees } \\
\mathrm{X}_{12}=\text { Number of Visitors } \\
\mathrm{X}_{13}=\text { Building Area }\end{array}$ \\
\hline
\end{tabular}
variables used are as follows:

Table 1 Research variable 


\begin{tabular}{|l|l|l|}
\hline No & $\begin{array}{c}\text { Response variable } \\
\text { (Dependent variable) }\end{array}$ & \multicolumn{1}{c|}{$\begin{array}{c}\text { Explanatory Variables } \\
\text { (Variable Free) }\end{array}$} \\
\hline 7 & Y $_{\text {Apotik }}$ & $\mathrm{X}_{14}=$ Number of Visitors \\
& & $\mathrm{X}_{15}=$ Building Area \\
\hline 8 & $\mathrm{Y}_{\text {Industri }}$ & $\mathrm{X}_{16}=$ Land Area \\
& & $\mathrm{X}_{17}=$ Number of Employees \\
& & $\mathrm{X}_{18}=$ ParkingArea \\
\hline 9 & $\mathrm{Y}_{\text {Rumah Sakit }}$ & $\mathrm{X}_{19}=$ Daily Patient Amount \\
& & $\mathrm{X}_{20}=$ Area of Inpatient Room \\
\hline
\end{tabular}

\section{Result}

\subsection{Characteristics of Waru Street - Mojokerto}

The type of road that connects Jalan Waru - Mojokerto is 4/2 UD or 2 undivided directions with 6 meters width of each line, hotmix asphalt pavement with good condition and has a median road of 0.5 meters. In accordance with the condition of the location of the study in the know Co $=6000 \mathrm{pcu} /$ hour, $\mathrm{FCw}=0.91, \mathrm{FCsp}=1, \mathrm{FCsf}=0.92$, and FCcs $=1$, as a result can be known the capacity of the road of $5023.2 \mathrm{pcu} /$ hour.

\subsection{Modeling of land use}

The results of linear regression analysis resulted in land use modeling for all species contained along Waru Street - Mojokerto as follows:

Table 2. Results of modeling of origin and destination from land use

\begin{tabular}{|c|c|c|c|}
\hline \multicolumn{2}{|c|}{ Land use } & Origin Modeling & Determination \\
\hline Housing & Residents & $\begin{array}{l}\text { YHousing }=-0,386+0,002 \mathrm{X} 1+5,569 \\
\mathrm{X} 2+0,00000000247 \mathrm{X} 3\end{array}$ & 1 \\
\hline \multicolumn{2}{|c|}{ Land use } & Destination Modeling & $\begin{array}{c}\text { Determination } \\
\text { Coeffisient }\end{array}$ \\
\hline \multirow[t]{2}{*}{ Education } & University & $Y_{\text {University }}=-0,355+0,008 \mathrm{X} 4+0,149 \times 5$ & 0.994 \\
\hline & TK-SMK/SMU & $\begin{array}{l}\text { YTK-SMK/SMU }_{\text {T }}=-0,254+0,505 \mathrm{X} 6+0,518 \times 7- \\
0,018 \mathrm{X} 8\end{array}$ & 1 \\
\hline \multirow[t]{4}{*}{$\begin{array}{l}\text { Trade and } \\
\text { Services }\end{array}$} & Trade & $Y_{\text {Trade }}=-0,431+0,075 \mathrm{X} 9$ & 1 \\
\hline & SPBU & $Y_{\text {SPBU }}=0,447+142,318 \times 10$ & 1 \\
\hline & Office & $\begin{array}{l}Y_{\text {Office }}=0,108+0,662 \times 11+0,659 \\
X 12+0,00007194 \text { X13 }\end{array}$ & 1 \\
\hline & Apotic & $Y_{\text {Apotic }}=25,323+0,322 \times 14+0,084 \mathrm{X} 15$ & 1 \\
\hline Industry & Industry & $\begin{array}{l}Y_{\text {Industry }}=-0,497-0,0000003505 \times 16+1,184 \\
X 17-0,000002801 \times 18\end{array}$ & 1 \\
\hline Medical & Hospital & $\mathrm{Y}_{\text {Hospital }}=13,715+0,291 \mathrm{X} 19+0,055 \mathrm{X} 20$ & 0.999 \\
\hline
\end{tabular}

\subsection{Movement of volume of vehicles and volume of land use}

By comparing the results of land use model with road capacity in getting the volume of vehicle movement in the following table. Peak volume of the largest movement is 12.253 smp / hour. The movement occurred at the peak hour at 17:00 to 18:00. the movement 
during peak hours is affected by the ratio of land use that reached $98 \%$. The lowest volume of movement occurred at 11:00 to 12:00 of 7,640 smp / hour. Where the ratio of land use only reaches $51 \%$ effect on road capacity which only reaches $5,023 \mathrm{smp} /$ hour.

\subsection{Model of land use interaction with road network}

The total movement of vehicles per hour in Jalan Waru - Mojokerto affects the level of service seen from its capacity. Calculation of the application of land use model in WaruMojokerto Street as a whole, then the result will interaksikan with Waru-Mojokerto road network system. The movement of vehicles from land use as the rise / pull and continuous current movement as well as the calculation of road service level by comparison of total volume with capacity can be seen in the following table.

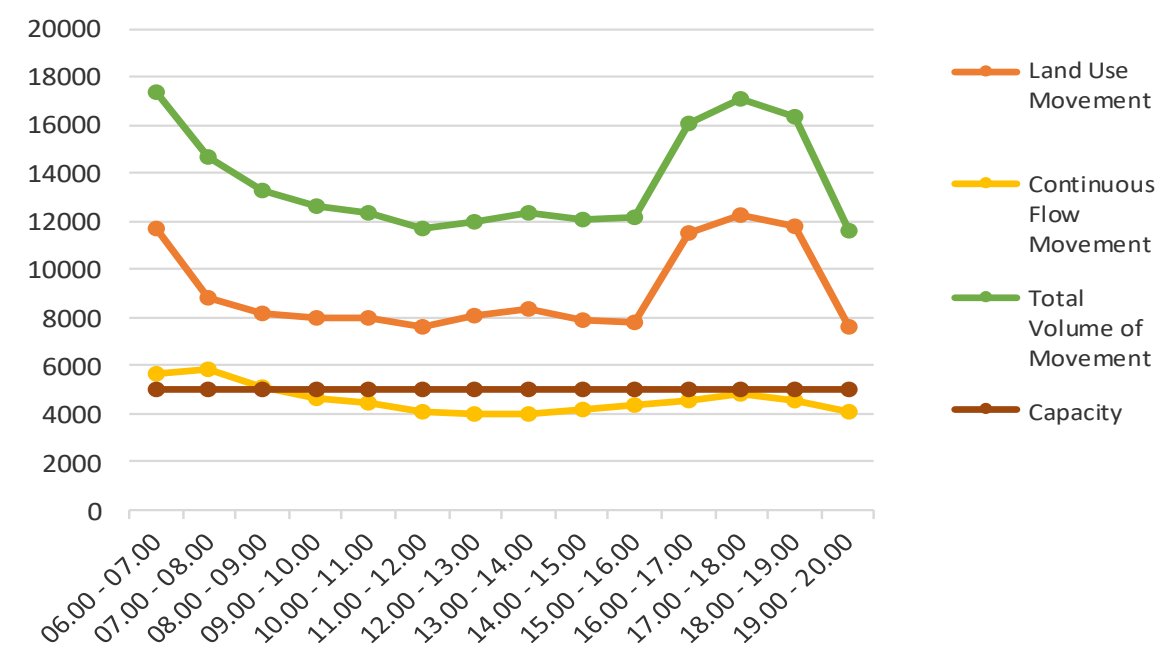

Fig. 1. Land use and road interaction

The interaction results of vehicle movement volumes from the rise / pull of land use with the road network system can show the performance of the road network or the level of road service. The calculation in the table above shows if at 6:00 to 20:00 the service level of the road is F. In the graph can also show the movement of the rise and / or pull along the road corridor has a very big influence compared with the continuous current. It affects the capacity of Jalan Waru-Mojokerto which is only $5023.2 \mathrm{smp} /$ hour.

\subsection{Estimated time travel}

The calculation of travel time can be calculated with known average density divided by road length. Based on the calculation of the volume of movement with road capacity in Jalan Waru - Mojokerto, the service level is F, where the average of the density can be reached $30 \mathrm{~km} /$ hour. To determine the estimated travel time to be achieved is to compare the length of the road with its speed. The length of the road is known $34 \mathrm{~km}$. Then get the time to travel is 68 minutes. 
Table 3. Calculation of Travel Time

\begin{tabular}{|c|c|c|c|c|c|c|c|}
\hline Time & $\begin{array}{c}\text { Movement } \\
\text { of Vehicles } \\
\text { from Land } \\
\text { Use } \\
\left(\mathbf{V}_{\mathbf{i}}\right)\end{array}$ & $\begin{array}{c}\text { Continuous } \\
\text { Flow } \\
\text { Movement } \\
\left(\mathbf{V}_{\text {eksternal }}\right.\end{array}$ & $\begin{array}{c}\text { Total } \\
\text { Volume } \\
\text { Movement }\end{array}$ & Capacity & $\begin{array}{c}\text { Ratio } \\
\text { V/C }\end{array}$ & LOS & $\begin{array}{c}\text { Travel } \\
\text { Time } \\
\text { (minutes) }\end{array}$ \\
\hline $06.00-07.00$ & 11739 & 5663 & 17402.0 & 5023.2 & 3.46 & $\mathrm{~F}$ & 68 \\
\hline $07.00-08.00$ & 8815 & 5887 & 14701.5 & 5023.2 & 2.93 & $\mathrm{~F}$ & 68 \\
\hline $08.00-09.00$ & 8199 & 5093 & 13292.1 & 5023.2 & 2.65 & $\mathrm{~F}$ & 68 \\
\hline $09.00-10.00$ & 7977 & 4663 & 12640.2 & 5023.2 & 2.52 & $\mathrm{~F}$ & 68 \\
\hline $10.00-11.00$ & 7970 & 4404 & 12374.1 & 5023.2 & 2.46 & $\mathrm{~F}$ & 68 \\
\hline $11.00-12.00$ & 7640 & 4037 & 11677.4 & 5023.2 & 2.32 & $\mathrm{~F}$ & 68 \\
\hline $12.00-13.00$ & 8047 & 3978 & 12025.2 & 5023.2 & 2.39 & $\mathrm{~F}$ & 68 \\
\hline $13.00-14.00$ & 8313 & 4008 & 12321.2 & 5023.2 & 2.45 & $\mathrm{~F}$ & 68 \\
\hline $14.00-15.00$ & 7887 & 4183 & 12070.0 & 5023.2 & 2.40 & $\mathrm{~F}$ & 68 \\
\hline $15.00-16.00$ & 7804 & 4386 & 12190.7 & 5023.2 & 2.43 & $\mathrm{~F}$ & 68 \\
\hline $16.00-17.00$ & 11553 & 4498 & 16051.1 & 5023.2 & 3.20 & $\mathrm{~F}$ & 68 \\
\hline $17.00-18.00$ & 12253 & 4866 & 17118.8 & 5023.2 & 3.41 & $\mathrm{~F}$ & 68 \\
\hline $18.00-19.00$ & 11777 & 4579 & 16355.9 & 5023.2 & 3.26 & $\mathrm{~F}$ & 68 \\
\hline $19.00-20.00$ & 7578 & 4040 & 11617.5 & 5023.2 & 2.31 & $\mathrm{~F}$ & 68 \\
\hline
\end{tabular}

Note: Length of road is $34 \mathrm{~km}$.

\section{Conclusion}

\subsection{Model of the relationship of traffic flow with travel time}

On the Waru Street- Mojokerto road segment, the volume of vehicle movement from the raised / pulled generated land $(127,551.35 \mathrm{pcu} / \mathrm{hour})$ is smaller than the continuous movement volume on the main road $(64,286 \mathrm{pcu} / \mathrm{hour})$. For land that contributes the largest volume of movement is the use of industrial land. So the more land to build land for land on the main road will have an impact on increasing the level of congestion on the main road.

For the service level of Jalan Waru - Mojokerto and Interaction Model of Land Use Road Network, it shows that at $06.00-\mathrm{s} / \mathrm{d}-20.00$ the level of service $=\mathrm{F}$. Meanwhile, the time required to take the road Waru Street - Mojokerto road with the length of the road 34 $\mathrm{km}$ is 68 minutes. Where the service level of the road $=\mathrm{F}$, so the speed is $30 \mathrm{~km} /$ hour.

\subsection{Components that affect the determination of travel time estimation}

The amount of travel time on the road depends on the amount of current and capacity of the road segment.

1. Influential components in road capacity calculation is basic capacity, capacity correction factor for road width, capacity factor due to directional distribution, capacity correction factor due to side interference and capacity correction factor due to city size.

2. Traffic flow is divided into two types, namely internal currents (land use movement) and external currents (continuous currents).

\section{References}

1. Tamin, O. Z. Perencanaan dan Permodelan Transportasi, Bandung: ITB. (2000)

2. Sahrullah, Ramli, M.I., Ali, N., Rahim, R., A travel time estimation model of private cars in urban arterial roads based on heterogeneous traffic. International Journal of Civil Engineering and Technology, Vol. 8(7), pp. 676-685. (2017) 
3. Damayanti, R. Pengaruh Guna Lahan dan Pola Pergerakan Terhadap Tingkat Pelayanan Jalan di Sekitar Bandara Soekarno Hatta. AGORA, Jurnal Arsitektur 2. (1997)

4. Kumalasari, D. Pengaruh Guna Lahan Terhadap Tarikan Pergerakan, Biaya Kemacetan, dan Biaya Kecelakaan (Di Jalan KH. Abdul Fatah - Jalan Kapten Kasihin Tulungagung). Jurnal Rekayasa Sipil 4. (2011)

5. Sugiarto, Budi W. Studi Pemasangan Indikator Estimasi Waktu Tempuh Perjalanan Antar Kota. Dinas Perhubungan dan Lalu Lintas Jalan. Jawa Timur. (2015) 